Poms can tell properly.

I saw him in Bangkok. He was the first to point out the error in my abstract in the programme that turned it into a Pommy collectors' item. "Penetrating Trauma in Australia is fortunately rear.." He sat in the front row of my lecture in a sea of Asian faces. I was also chairman. There was a very serious Yank talking who, before we started, asked me to invite the crowd to the front at the end as he would intubate his own trachea under local. I invited them and told them that the organising committee members were so impressed they had invited him back next year to talk about rigid sigmoidoscopy. Throughout the session, I was conscious of Michael quietly giggling.

I remember the boat trip on Pittwater when Michael met us at Church Point just before we left. He had needed to bribe the taxi driver to drive very fast. I remember his story about doing a tracheostomy on an automobile squillionaire who was hanging in a tree, and using the offered reward for a scholarship for a trauma fellow. I remember many stories, some of which I heard elsewhere with other heroes or villain. What the hell, if the story was good and well told.

Among the many things Michael Moles taught me was his theory for language for travelers. Although a talented linguist, he believed it was foolish for such as myself to try to learn another language with limited opportunities to practice it. Mike believed one should learn the three key phrases in as many languages as possible. The phrases were:

"How much is that?"

"Can I have another one of those, please?"

"My friend will pay."

He recently agreed with my suggestion that another should be added; "A carafe of the house red wine, please."

Michael was a sailor of great courage and a soldier of great prowess. He left medicine and the world better for his presence.

And he left it short one more charismatic doctor of the larrikin mode. We will not see his like again.

\section{A True Humanitarian: In Memoriam}

\section{Marvin L. Birnbaum}

\section{Editor-in-Chief}

All of us who were touched by this person grieve at our loss-all of us. There are few people that we encounter in our lifetime that leave such an indelible mark upon us as did Michael Moles. Was it the persistent twinkle in his eyes, his dogged safari outfit, his gangling, angular figure, the tone and pacing of his speech, his boyish enthusiasm, or was it his facility with the English language? Or could it have been the agility of his mind, his unwavering dedication and commitment to humanitarian causes, his deep and abiding concern for the human condition, his ability to recognize when he was mistaken and rapidly and sincerely make amends, the scope of his knowledge and experience cloaked deeply in humility, or his skill at flushing out the essence of an issue, and then, articulating it so eloquently? What was it that drew each of us mourning our loss so closely to this character?

This magnetic character somehow got into each of us and became a part of us. Michael even became a part of those of us who only saw or worked with him in very short bursts and at infrequent, widely separated intervals. He dug his way into us and forever has become a part of us. He lives on in us, in all of his students, and in all of those downtrodden he touched in a way to make their lives better. Through them, Michael lives on in the thousands who never had the experience of meeting him or even imagining the impact he had upon their lives.

Michael was a quiet, unassuming leader, a clever (but rarely sneaky!) fellow who never sought self-aggrandisement, who never sought riches, but who oozed love for his fellow human beings. He stood for what was right: insisting that whatever he was associated with was right.

This often ghostly figure has set a standard for our profession. Michael lives on inside of all of us-just look, you will find it, and you will smile for having had him as part of your life. Yes, we have much to celebrate! 